\title{
Population Variability, Selection Impact and Genotypic Response in Biennial Cycles of Reproductive Stressed Rainfed Rice
}

\author{
Prafull Kumar ${ }^{1}$, A. K. Gupta ${ }^{1}$, R. R. Kanwar ${ }^{1}$, Poonam Kumari ${ }^{2}$ \\ ${ }^{1}$ S.G. College of Agriculture and Research Station, Jagdalpur, Indira Gandhi Krishi Vishvavidyalaya, \\ Raipur, C.G. (492 012 ), India \\ ${ }^{2}$ Punjab Agricultural University, Ludhiana, Punjab (141 004), India
}

\section{Article History}

Manuscript No. AR1447

Received in $22^{\text {nd }}$ August, 2015

Received in revised form $14^{\text {th }}$ March, 2016

Accepted in final form $25^{\text {th }}$ July, 2016

\section{Correspondence to}

*E-mail: prafull397@gmail.com

\section{Keywords}

Upland rice, rainfed agriculture, reproductive stress, genetic components, GCV

\begin{abstract}
Biennial field experiment (2013-14) was conducted at the S.G. College of Agriculture and Research Station, Jagdalpur; Chhattisgarh, India to study the extent of population variability, impact of selection over them and adaptability to rainfed ecology. After first selection cycle, the retained variability in selection criteria was high and accounted for 20.65 and $17.03 \%$ (phenotypic and genotypic) hence further cycle of selection could be practiced for improvement. The maximum phenotypic and genotypic coefficients of variation was observed for crop biomass i.e. biological yield plot $^{-1}(24.27$ and $19.57 \%)$ followed by grain yield (20.65 and $17.03 \%)$ and harvest index (17.75 and $15.67 \%)$. The inferior variability coefficients call for addition of newer genotypes and crossing programmes. The estimates of heritability ranged between $44 \%$ (panicle length) to $84 \%$ (harvest index). Higher magnitude of heritability was recorded for harvest index (84\%), spikelet fertility (77\%), days to 50\% flowering (75\%), and crop duration (64\%). High estimate of heritability coupled with high genetic advances were observed for harvest index ( $84 \%$ and 29.46, heritability and genetic advance respectively), biological yield plot $^{-1}$ (56\% and 24.47$)$ and grain yield (48\% and 21.16). This stumpy intensity of trait transmissibility and genetic gain is owing to unpredictable microenvironment of upland rice. Traits like crop biomass, grain yield and harvest index are concluded critical for rainfed breeding and since possessing high heritability and genetic advance, can be improved by adapting component and direct selection.
\end{abstract}

\section{Introduction}

Around 3 billion people of the world use rice as a critical or basic food that provides 50 to $80 \%$ of their daily calories (Sohrabi et al., 2012; Lakew et al., 2014). Rice is cultivated on more than 150 mha of global acreage with around 600 mt production (Guimaraes, 2013) under four different land types viz., irrigated, 57\%; rainfed lowland, 37\%, upland, 9\%, deep water, 3\% (IRRI, 2009). Hence, soil water conditions also differ wholly with cultivation type; irrigated paddy condition is anaerobic, rainfed lowland alternatively aerobic and anaerobic and upland, aerobic. Upland rice comprises eleven percent of global rice production and is cultivated on around 14 mha. Upland rice has a small contribution in total production but is major food in some developing countries namely India, Bangladesh, Indonesia, and Philippines that plant the most upland rice, but the yield is so low (about 1 t ha- ${ }^{-1}$ on average) and highly variable ( Musa et al., 2009; Reuveni, 2011). Rice plants adapt to rainfed and or dryland ecosystem by several mechanisms viz., ephemerism, deep or extensive root systems which have the ability to gather water over a wide area, store up water in their tissues and release it very slowly, protected from water loss by wax or other impediments etc. Since all above mechanism are regulated by plant genetics, it becomes necessary to understand and modify the expression according to prevailing moisture availability.

Rather than field and crop management, genetic manipulation of crop architecture is reliable option for sustainable rainfed agriculture which calls for magnitude of genetic variability lying in base population. Environmental effects and fluctuations influence the total observable variations of both quantitative qualitative traits (Lingaiah et al., 2014). Therefore, partitioning of overall variance due to genetic and non-genetic causes becomes necessary for effective breeding programme (Augustina et al., 2013). Hence, looking for present scenario of upland rice and underlying 
genetic manipulation need, investigation was framed with 23 genotypes to study effect of selection over existing variability and superior genotypes for dryland rice.

\section{Materials and Methods}

Field experiment was conducted at the S.G. College of Agriculture and Research Station, Jagdalpur; Chhattisgarh, India over a period of two years (2013-2014). Jagdalpur is the rainfed plateau zone of Chhattisgarh having annual rainfall $1100 \mathrm{~mm}$. It lies within latitude $19.05^{\circ} \mathrm{N}$ and Longitude $81.57^{\circ} \mathrm{E}$. The rainfed experiment was laid out in Randomized Complete Block Design (RCBD) with three replicates. The plot size was $5 \times 3$ and $5 \times 2.6 \mathrm{~m}^{2}$ on gross and net basis respectively. Eighteen genotypes obtained from Indira Gandhi Krishi Vishwavidyalaya, Raipur, were evaluated for adaptability and suitability in plateau breeding. These genotypes were R-RF-69, R-RF-84, R-RF-95, R-RF65, IR 84887-B-15, IR 83929-B-B-132-2, IR 86857-46-1-12, R-RF-45, PM 6004, IR 83381-B-B-137-3, Sahbhagidhan, IR 88287-677-60-3, IR 84852-B-12-1-4, IR 88287-677-533, IR 83383-B-B-141-1, IR 84859-B-41-1-2, IR 86857-461-1-2, Narendra 97. Morphological data were collected for 10 quantitative characters at appropriate growth stage namely Days to flowering, days to maturity, Plant height, panicles per square meter, panicle length, spikelet panicle ${ }^{-1}$, spikelet fertility, Grain yield (q ha-1), Number of panicles $\mathrm{m}^{-2}$, grain yield plot $^{-1}$, biological yield and harvest index. Phenotypic, Genotypic and environmental variances were done using the formula of Uguru (2005) from modification of Asante and Dixon (2002). Heritability estimates were done according to Burton and Devane (1953).

\section{Results and Discussion}

Rainfed upland rice is grown in unbunded fields where over soil drainage and/or uneven land surface renders the accumulation of water impracticable. Upland rice is usually grown in systems where little or no fertilizer is applied, and is direct-seeded into unpuddled, unsaturated soil (Atlin et al., 2004). Furthermore, $25 \%$ of the fields used for upland crop production are prone to yield reductions as a consequence of drought (Kasuka et al., 2005). Drought therefore has a major impact on world agriculture. Drought may happen at any time during the growing season and may occur every year in some areas. Crop breeding is important tool for alleviating drought stress through improved water use efficiency and genetic buffer which consecutively comes from variability persisting in the population (Ravindra Babu et al., 2012).

\subsection{First cycle of selection}

Analysis of variance revealed significant differences among test genotypes for all traits under study. In kharif, 2013, phenotypic coefficient of variation was higher than genotypic counterpart, indicating role of prevailing micro and macro environment in expression of quantitative traits (Table 1; Figure 01). The maximum phenotypic and genotypic coefficients of variation was observed for crop biomass i.e. biological yield $\operatorname{plot}^{-1}(24.27$ and $19.57 \%$ ) followed by grain yield (20.65 and $17.03 \%)$ and harvest index (17.75 and 15.67\%). In this regards, Karthikeyan et al. (2009) have discussed high percentage for PCV and GCV for straw yield plant ${ }^{-1}$, grain yield plant ${ }^{-1}$, biological yield plant ${ }^{-1}$, fertile florets percentage and number of branches panicle $^{-1}$; Anjaneyulu et al. (2010) for number of grain panicle ${ }^{-1}$, fertility per cent and grain yield plant ${ }^{-1}$; Kumar and Senapati, (2013) for grain yield, panicle weight, number of panicles plant $^{-1}$, number of secondary branches panicle ${ }^{-1}$, number of grains panicle ${ }^{-1}$, test weight and florets number panicle ${ }^{-1}$ and Ketan and Sarkar, (2014) for number of grains panicle ${ }^{-1}$, panicle weight, florets number panicle ${ }^{-1}$, number of secondary branches, grain yield plant ${ }^{-1}$ and 1000 grain weight. Traits like days to flowering, spikelet fertility and crop duration exhibited lower values and narrow margin between two variability coefficients as well (3.45 and 3.26, 3.83 and 3.47, 2.92 and 2.64\%). Earlier, Yadav et al., 2010; Pfukrei et al., 2011 have also discussed this narrow range as relative stabilization of the trait in concerned environment. The heritability was maximum in days to flowering (0.89) followed by plant height $(0.88)$, spikelet fertility (0.82) and crop duration (0.81). However, in contrast to Kumar et al., 2014; heritability for grain yield was comparatively lower hence, to draw reliable conclusion, heritability and genetic advance is always suggested to consider together. Here, high heritability coupled with high genetic advance $(p<0.05)$ was observed for all yield parameters i.e. being governed by additive genetic factors and can be improved through limited selection cycles.

\subsection{Second cycle of selection}

In the second year of experiment (kharif, 2014) the difference between genotypic and phenotypic coefficient of variation was less for all characters studied except panicles $\mathrm{m}^{-2}$, spikelet panicle $^{-1}$ and grain yield. The slight difference between genotypic and phenotypic coefficients is confirmatory evidence of lesser environmental role (Seyoum et al., 2012; Dhanwani et al., 2013). Among the reproductive parameters the high percent of genotypic and phenotypic coefficients were recorded for grain yield (15.27 and 22.08) followed by panicles $\mathrm{m}^{-2}$ (16.54 and 19.41) and biological yield (14.52 and 16.87) while the lowest was recorded for spikelet fertility (2.52 and 2.98) (Table 2; Figure 2). High proportion of two coefficients shows the improvement scope of final plant product i.e. grain yield (Ravindra Babu et al., 2012). Therefore selection on the basis of phenotype alone can be effective for the improvement of these traits. Similar results for low to moderate values of GCV and PCV were also reported by Prajapati et al. (2011) and Singh et al. (2011). The estimates of heritability act as predictive instrument in expressing the reliability of phenotypic value. 
Table 1: Summary of genetic parameters after first selection cycle (year, 2013)

\begin{tabular}{|c|c|c|c|c|c|c|c|c|c|c|}
\hline & $\begin{array}{c}\text { Days to } \\
\text { flower- } \\
\text { ing } \\
\end{array}$ & $\begin{array}{c}\text { Crop } \\
\text { dura- } \\
\text { tion }\end{array}$ & $\begin{array}{l}\text { Plant } \\
\text { height } \\
(\mathrm{cm})\end{array}$ & $\begin{array}{c}\text { Panicles } \\
\mathrm{m}^{-2}\end{array}$ & $\begin{array}{l}\text { Panicle } \\
\text { length } \\
(\mathrm{cm})\end{array}$ & $\begin{array}{l}\text { Spikelets } \\
\text { panicle }^{-1}\end{array}$ & $\begin{array}{l}\text { Spikelet } \\
\text { fertility } \\
(\%)\end{array}$ & $\begin{array}{c}\text { Grain } \\
\text { yield } \\
\left(\mathrm{kg} \mathrm{Plot}^{-1}\right)\end{array}$ & $\begin{array}{c}\text { Biologi- } \\
\text { cal yield } \\
\left(\mathrm{kg} \mathrm{Plot}^{-1}\right)\end{array}$ & $\begin{array}{c}\text { Harvest } \\
\text { index } \\
(\%) \\
\end{array}$ \\
\hline Var environmental & 0.84 & 1.97 & 13.86 & 689.01 & 1.72 & 19.76 & 2.06 & 0.07 & 0.90 & 8.13 \\
\hline ECV & 1.13 & 1.26 & 4.13 & 9.67 & 5.98 & 5.40 & 1.62 & 11.68 & 14.30 & 8.35 \\
\hline Var genotypical & 6.95 & 8.63 & 97.73 & 1069.58 & 1.12 & 19.89 & 9.40 & 0.14 & 1.68 & 28.61 \\
\hline GCV & 3.26 & 2.64 & 10.96 & 12.05 & 4.82 & 5.42 & 3.47 & 17.03 & 19.57 & 15.67 \\
\hline Var phenotypical & 7.79 & 10.60 & 111.58 & 1758.59 & 2.84 & 39.65 & 11.46 & 0.21 & 2.58 & 36.73 \\
\hline $\mathrm{PCV}$ & 3.45 & 2.92 & 11.71 & 15.46 & 7.69 & 7.65 & 3.83 & 20.65 & 24.24 & 17.75 \\
\hline $\mathrm{h}^{2}$ (Broad sense) & 0.89 & 0.81 & 0.88 & 0.61 & 0.39 & 0.50 & 0.82 & 0.68 & 0.65 & 0.78 \\
\hline $\begin{array}{l}\text { Genetic } \\
\text { advancement 5\% }\end{array}$ & 5.13 & 5.46 & 19.06 & 52.54 & 1.37 & 6.51 & 5.72 & 0.64 & 2.16 & 9.72 \\
\hline $\begin{array}{l}\text { Genetic } \\
\text { advancement } 1 \%\end{array}$ & 6.57 & 7.00 & 24.42 & 67.33 & 1.75 & 8.34 & 7.33 & 0.82 & 2.77 & 12.46 \\
\hline $\begin{array}{l}\text { Gen. Adv as } \% \text { of } \\
\text { mean } 5 \%\end{array}$ & 6.33 & 4.90 & 21.12 & 19.36 & 6.24 & 7.91 & 6.47 & 28.92 & 32.55 & 28.48 \\
\hline $\begin{array}{l}\text { Gen. Adv as } \% \text { of } \\
\text { mean } 1 \%\end{array}$ & 8.12 & 6.28 & 27.07 & 24.82 & 7.99 & 10.13 & 8.29 & 37.07 & 41.72 & 36.50 \\
\hline General mean & 80.97 & 111.36 & 90.22 & 271.33 & 21.92 & 82.28 & 88.39 & 2.21 & 6.63 & 34.14 \\
\hline $\begin{array}{l}\text { Exp mean next } \\
\text { generation }\end{array}$ & 86.10 & 116.82 & 109.28 & 323.87 & 23.28 & 88.78 & 94.11 & 2.85 & 8.79 & 43.86 \\
\hline
\end{tabular}

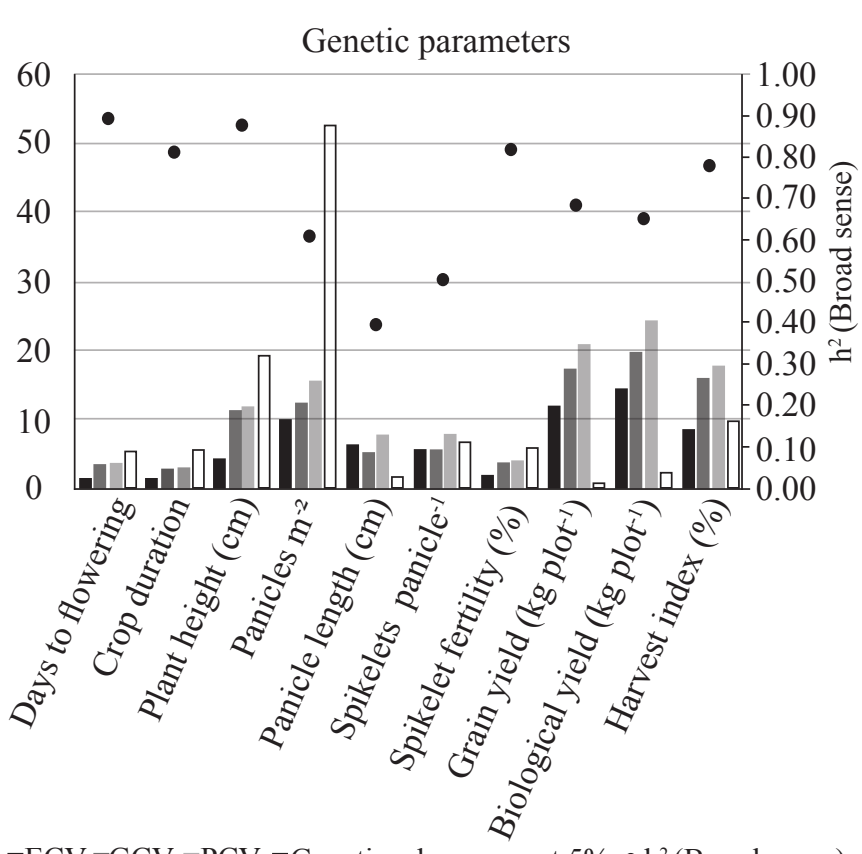

- ECV $\mathrm{mGCV} \backsim \mathrm{PCV} \square$ Genetic advancement $5 \% \bullet \mathrm{h}^{2}$ (Broad sense)

Figure 1: Genetic parameters after first selection cycle

Therefore, high heritability helps in effective selection for a particular character (Sahu et al., 2014). In the present study, all the characters exhibited high heritability, which ranged from 0.48 to 0.96 however for grain yield heritability was quite lower (0.48) (Table 2). The genetic advance is a useful indicator of the progress that can be expected as a result of exercising selection on the pertinent population. The genetic advance expressed as a percentage of mean ranged from 753.41 to 0.08 and the important characters like seed vigor, days to maturity, plant height, days to $50 \%$ flowering and spikelet sterility recorded higher estimates.

Improving upland rice productivity is essential to meet rice food security and needs of impoverished upland communities. In this perspective, breeding drought-resistant rice genotypes is an increasingly important goal. Numerous secondary characters have been suggested to help plant breeders in their selections, but most of these traits are not used in selection, as they are not practical for selection purposes, exhibit low heritability, or are not highly correlated with grain yield. Standardization of drought screening has been shown to increase the heritability of yield under stress to values similar to those obtained for yield in well-watered conditions. From the first selection cycle, it can be concluded that drought tolerant upland genotypes can be bred by directly selecting for yield in stress environments.

\subsection{Pooled over selection environments}

Considerable range of variation was observed for all the traits under study indicating enough scope for bringing about improvement in the desire direction. Both genotypic and phenotypic coefficients of variation i.e. PCV and GCV estimates were moderately higher for grain yield (14.84 and 21.45 ) followed by biological yield plot $^{-1}$ (15.84 and 21.11) 


\begin{tabular}{|c|c|c|c|c|c|c|c|c|c|c|}
\hline & $\begin{array}{l}\text { Days to } \\
\text { flower- } \\
\text { ing }\end{array}$ & $\begin{array}{c}\text { Crop } \\
\text { dura- } \\
\text { tion }\end{array}$ & $\begin{array}{l}\text { Plant } \\
\text { height } \\
(\mathrm{cm})\end{array}$ & $\begin{array}{c}\text { Panicles } \\
\mathrm{m}^{-2}\end{array}$ & $\begin{array}{c}\text { Panicle } \\
\text { length } \\
(\mathrm{cm})\end{array}$ & $\begin{array}{l}\text { Spike- } \\
\text { lets } \\
\text { pani- } \\
\text { cle }^{-1}\end{array}$ & $\begin{array}{l}\text { Spike- } \\
\text { let } \\
\text { fertility } \\
(\%)\end{array}$ & $\begin{array}{c}\text { Grain } \\
\text { yield } \\
\left(\mathrm{kg} \mathrm{plot}^{-1}\right)\end{array}$ & $\begin{array}{c}\text { Biological } \\
\text { yield } \\
\left(\mathrm{kg} \mathrm{plot}^{-1}\right)\end{array}$ & $\begin{array}{c}\text { Harvest } \\
\text { index } \\
(\%)\end{array}$ \\
\hline Var environmental & 0.69 & 1.91 & 33.13 & 741.47 & 1.00 & 40.32 & 2.14 & 0.15 & 0.29 & 9.52 \\
\hline $\mathrm{ECV}$ & 0.94 & 1.18 & 6.46 & 10.15 & 5.02 & 8.34 & 1.58 & 15.95 & 8.57 & 7.98 \\
\hline Var genotypical & 17.49 & 15.00 & 108.85 & 1968.03 & 1.07 & 99.99 & 5.42 & 0.13 & 0.82 & 31.35 \\
\hline GCV & 4.73 & 3.30 & 11.70 & 16.54 & 5.19 & 13.13 & 2.52 & 15.27 & 14.52 & 14.49 \\
\hline Var phenotypical & 18.18 & 16.91 & 141.98 & 2709.50 & 2.07 & 140.31 & 7.55 & 0.28 & 1.11 & 40.87 \\
\hline PCV & 4.82 & 3.50 & 13.36 & 19.41 & 7.22 & 15.55 & 2.98 & 22.08 & 16.87 & 16.55 \\
\hline $\mathrm{h}^{2}$ (Broad sense) & 0.96 & 0.89 & 0.77 & 0.73 & 0.52 & 0.71 & 0.72 & 0.48 & 0.74 & 0.77 \\
\hline $\begin{array}{l}\text { Genetic advance- } \\
\text { ment } 5 \%\end{array}$ & 8.45 & 7.51 & 18.82 & 77.89 & 1.53 & 17.39 & 4.06 & 0.52 & 1.61 & 10.10 \\
\hline $\begin{array}{l}\text { Genetic advance- } \\
\text { ment } 1 \%\end{array}$ & 10.83 & 9.63 & 24.12 & 99.81 & 1.96 & 22.28 & 5.20 & 0.67 & 2.06 & 12.95 \\
\hline $\begin{array}{l}\text { Gen. Adv as \% of } \\
\text { Mean } 5 \%\end{array}$ & 9.55 & 6.40 & 21.10 & 29.04 & 7.68 & 22.83 & 4.40 & 21.75 & 25.76 & 26.15 \\
\hline $\begin{array}{l}\text { Gen. Adv as } \% \text { of } \\
\text { mean } 1 \%\end{array}$ & 12.24 & 8.20 & 27.05 & 37.22 & 9.84 & 29.26 & 5.63 & 27.88 & 33.02 & 33.51 \\
\hline General mean & 88.47 & 117.47 & 89.17 & 268.17 & 19.90 & 76.17 & 92.39 & 2.40 & 6.23 & 38.64 \\
\hline $\begin{array}{l}\text { Exp mean next } \\
\text { generation }\end{array}$ & 96.92 & 124.99 & 107.98 & 346.05 & 21.43 & 93.56 & 96.45 & 2.92 & 7.84 & 48.74 \\
\hline
\end{tabular}

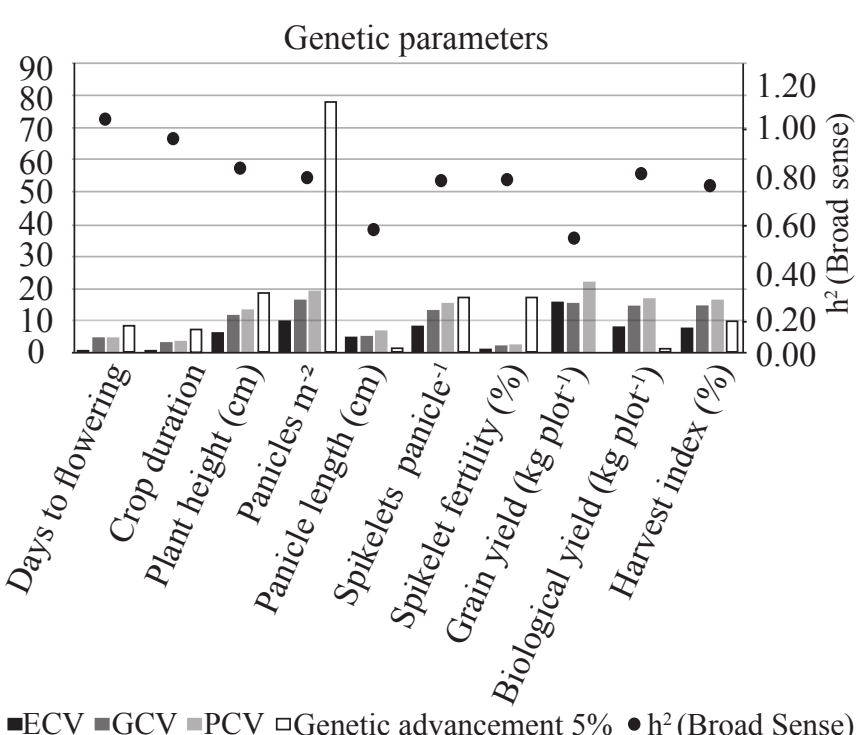

Figure 2: Genetic parameters after second selection cycle

and harvest index (15.65 and 17.12) (Table 03; Figure 03). However nomenclature of extant of variability to high, moderate or low depends upon crop species. Low magnitude of variation component shows the lack of variation among test population which requires crossing programmes and or addition of newer genotypes to enhance the variability level.
In contrast to Chavan et al. (2010), the difference between PCV and GCV were considerably higher for grain yield and biological yield plot $^{-1}$, indicating significant contribution of environmental variation towards expression of these traits. Thus selection based on phenotypic performance of these characters would be less effective to bring about considerable improvement in these characters.

The estimates of heritability ranged between $44 \%$ (panicle length) to $84 \%$ (harvest index). Higher magnitude of heritability was recorded for harvest index (84\%), spikelet fertility (77\%), days to $50 \%$ flowering $(75 \%)$, and crop duration (64\%). While the traits like crop duration, biological yield, spikelets panicle ${ }^{-1}$ and grain yield recorded moderate degree of heritability over both the environments. High heritability does not mean a high genetic advance for a particular quantitative character. As per previous reports, heritability estimates along with genetic gain would be more rewarding than heritability alone in predicting the consequential effect of selection to choose the best individual. High estimate of heritability coupled with high genetic advances were observed for harvest index ( $84 \%$ and 29.46 , heritability and genetic advance respectively), biological yield plot $^{-1}$ (56\% and 24.47) and grain yield (48\% and 21.16). These results suggests that these characters can be considered as favourable attributes for the improvement through selection and this may be due to additive gene action could be improved 


\begin{tabular}{|c|c|c|c|c|c|c|c|c|c|c|}
\hline & $\begin{array}{c}\text { Days to } \\
\text { flower- } \\
\text { ing }\end{array}$ & $\begin{array}{c}\text { Crop } \\
\text { dura- } \\
\text { tion } \\
\end{array}$ & $\begin{array}{l}\text { Plant } \\
\text { height } \\
(\mathrm{cm})\end{array}$ & $\begin{array}{c}\text { Panicles } \\
\mathrm{m}^{-2}\end{array}$ & $\begin{array}{l}\text { Panicle } \\
\text { length } \\
(\mathrm{cm})\end{array}$ & $\begin{array}{l}\text { Spikelets } \\
\text { panicle }^{-1}\end{array}$ & $\begin{array}{c}\text { Spikelet } \\
\text { fertility } \\
(\%)\end{array}$ & $\begin{array}{c}\text { Grain } \\
\text { yield } \\
\left(\mathrm{kg} \mathrm{plot}^{-1}\right)\end{array}$ & $\begin{array}{c}\text { Biological } \\
\text { yield } \\
\left(\mathrm{kg} \mathrm{plot}^{-1}\right)\end{array}$ & $\begin{array}{c}\text { Harvest } \\
\text { index } \\
(\%)\end{array}$ \\
\hline Var environmental & 3.21 & 5.12 & 45.61 & 1171.36 & 1.37 & 45.51 & 2.22 & 0.13 & 0.81 & 6.38 \\
\hline $\mathrm{ECV}$ & 2.11 & 1.98 & 7.53 & 12.69 & 5.59 & 8.52 & 1.65 & 15.48 & 13.96 & 6.94 \\
\hline Var genotypical & 9.78 & 8.63 & 81.17 & 1062.69 & 1.08 & 44.48 & 7.28 & 0.12 & 1.04 & 32.42 \\
\hline GCV & 3.69 & 2.57 & 10.04 & 12.08 & 4.98 & 8.42 & 2.99 & 14.84 & 15.84 & 15.65 \\
\hline Var phenotypical & 12.99 & 13.75 & 126.78 & 2234.05 & 2.45 & 89.98 & 9.51 & 0.24 & 1.84 & 38.80 \\
\hline $\mathrm{PCV}$ & 4.25 & 3.24 & 12.55 & 17.52 & 7.49 & 11.97 & 3.41 & 21.45 & 21.11 & 17.12 \\
\hline $\mathrm{h}^{2}$ (Broad sense) & 0.75 & 0.63 & 0.64 & 0.48 & 0.44 & 0.49 & 0.77 & 0.48 & 0.56 & 0.84 \\
\hline $\begin{array}{l}\text { Genetic } \\
\text { advancement 5\% }\end{array}$ & 5.59 & 4.79 & 14.85 & 46.32 & 1.43 & 9.66 & 4.87 & 0.49 & 1.57 & 10.72 \\
\hline $\begin{array}{l}\text { Genetic } \\
\text { advancement } 1 \%\end{array}$ & 7.16 & 6.14 & 19.03 & 59.36 & 1.83 & 12.38 & 6.24 & 0.63 & 2.02 & 13.74 \\
\hline $\begin{array}{l}\text { Gen. adv as \% of } \\
\text { Mean } 5 \%\end{array}$ & 6.60 & 4.19 & 16.56 & 17.17 & 6.82 & 12.19 & 5.38 & 21.16 & 24.47 & 29.46 \\
\hline $\begin{array}{l}\text { Gen. adv as } \% \text { of } \\
\text { mean } 1 \%\end{array}$ & 8.46 & 5.37 & 21.22 & 22.00 & 8.74 & 15.62 & 6.90 & 27.12 & 31.36 & 37.76 \\
\hline General mean & 84.72 & 114.42 & 89.69 & 269.75 & 20.91 & 79.22 & 90.39 & 2.31 & 6.43 & 36.39 \\
\hline $\begin{array}{l}\text { Exp mean next } \\
\text { generation }\end{array}$ & 90.31 & 119.21 & 104.54 & 316.07 & 22.33 & 88.88 & 95.26 & 2.79 & 8.01 & 47.11 \\
\hline
\end{tabular}

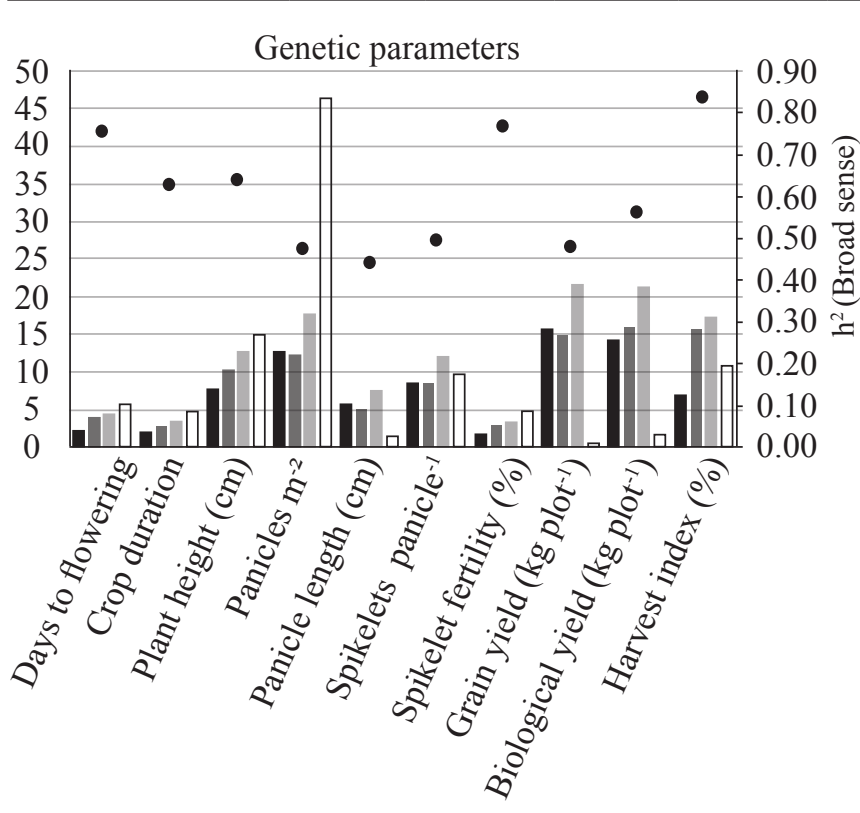

$\bullet \mathrm{ECV} \backsim \mathrm{GCV} \backsim \mathrm{PCV} \square$ Genetic advancement $5 \% \bullet \mathrm{h}^{2}$ (Broad sense)

Figure 3: Genetic parameters pooled over selection cycle

upon by adapting selection without progeny testing . On other hand days to $50 \%$ flowering ( $75 \%$ and 6.60 ), crop duration (63\% and 4.19), panicle length (44\% and 6.82), and spikelet fertility (77\% and 5.38) showed high heritability associated with low genetic advances revealing the predominance of non-additive gene action.

\section{Conclusion}

Occurrence of high heritability coupled with genetic advance may be inferred that the genotypic variance for these traits were primary due to additive genetic effect and selection based on phenotypic performance could be worth in achieving desired results. Observations suggest for more emphasis on yield contributing characters with high heritability, genetic advance and significant positive association. Since dryland crop breeding is location oriented challenge, their role in genetic behavior should be recognized; therefore useful to provide basic comprehension about crop genetics under uncertain whether protocols.

\section{Acknowledgement}

The authors acknowledge Department of Genetics and plant Breeding, IGKV, Raipur for proving breeding material and financial assistance.

\section{References}

Ananadrao, S.D., Singh, C.M., Suresh, B.G., Lavanya, G.R., 2011. Evaluation of rice hybrids for yield and yield component characters under North East Plain Zone. The Allahabad farmer 67(1), 63-68.

Anjaneyulu, M., Reddy, D.R., Reddy, K.H.P., 2010. Genetic variability, heritability and genetic advance in rice (Oryza sativa L.). Research on Crops 11, 415-16. 
Asante, I.K., Dixon, A.G.O., 2002. Heritability studies of some cassava Genotypes. West African Journal of Applied Ecology 3, 49-53.

Atlin, G.N., Laza, M., Amante, M., Lafitte, H.R., 2004. Agronomic performances of tropical aerobic, irrigated, and traditional upland rice varieties in three hydrological environments at IRRI, in New directions for a diverse planet. In: Proceedings of the $4^{\text {th }}$ International Crop Science Congress, Ed by Fisher, T., Turner, N., Angus, J., McIntyre., L., Robertson, M., Borrell, A., Lloyd, D., Brisbane, Australia.

Augustina, U.A., Iwunor, O.A., Ijeoma, O.R., 2013. Heritability and character correlation among some rice genotypes for yield and yield components. West African Journal of Applied Ecology 1(2), 73-84.

Burton, G.W., Devane, E.H., 1955. Estimating heritability in tall Fescue (Festuca arundinacea) from replicated clonal material. Agronomy Journal 7, 478-481.

Chavan, S.K., Mahajan, R.C., Fatak, S.U., 2010. Genetic variability studies in sorghum. Karnataka Journal of Agricultral Science 23(2), 322-323.

Dhanwani, R.K., Sarawgi, A.K., Solanki, A., Tiwari, J.K., 2013. Genetic variability analysis for various yield attributing and quality traits in rice (O. sativa L.). The Bioscan 8(4), 1403-1407.

Guimaraes, E.P., 2009. Rice breeding in Cereals. M.J. Carena, Ed., Springer, New York, NY, USA, 1-28.

Guimaraes, C.M., Luis, F.S., Paulo, H.N.R., Ana, C.D.L.S., 2013. Tolerance of upland rice genotypes to water deficit. Revista Brasileira de Engenharia Agricola e Ambiental 17(8), 805-810.

IRRI. 2009. Farm data-rice ecosystem, 30. Distribution of rice crop area, by environment. In: IRRI ed., IRRI world rice statistics. International Rice Research institute, Los Banos, Phillipines.

Karthikeyan, P., Anbuselvam, Y., Elangaimannan, R., Venkatesan, M., 2009. Variability and heritability studies in rice (Oryza sativa L.) under coastal salinity. Electronic Journal of Plant Breeding 1, 196-98.

Kasuka, M., Lalusin, A.G., Fujimura, T., 2005. The maintenance of growth and turgor in pearl millet (Pennisetum glaucum [L.] Leeke) cultivars with different root structures and osmo-regulation under drought stress. Plant Science 168, 1-14.

Ketan, R., Sarkar, G., 2014. Studies on variability, heritability, genetic advance and path analysis in some indigenous Aman rice (Oryza sativa L.). Journal of Crop and Weed 10(2), 308-315.

Kumar, Prafull, Dhillon, S.K., Sao, A., 2014.Genetic analysis of sunflower genotypes under water stress environments. International Journal of Farm Science 4(4), 26-35.

Kumar, A., Senapati, B.K., 2013. Genetic parameters and association studies for important quantitative traits in advanced lines of Sambamahsuri derivatives. Journal of Crop and Weed 9, 156-63.

Lakew, T., Tariku, S., Alem, T., Bitew, M., 2014. Agronomic performances and stability analysis of upland rice genotypes in North West Ethiopia. International Journal of Scientific and Research Publication 4(4), 1-9.

Lingaiah, N., Venkanna, V., Cheralu, C., 2014. Genetic Variability Analysis in Rice (Oryza sativa L.). International Journal of Pure and Applied Bioscience 2(5), 203-204.

Musa, M.H., Azemi, H., Juraimi, A.S., Mohamed, T.M., 2009. Upland rice varieties in Malaysia: agronomic and soil physico-chemical characteristics. Pertanika Journal of Tropical Agricultural Science 32(2), 225-246.

Pfukrei, K., Kumar, A., Tyagi, W., Rai, M., Pattanayak, A., 2011. Genetic variability in yield and its components in upland rice grown in acid soils of North East India. Journal of Rice Research 4, 4-7.

Prajapati, M., Singh, C.M., Suresh, B.G., Lavanya, G.R., Jadhav, P., 2011. Genetic parameters for grain yield and its component characters in rice. Electronic Journal Plant Breeding 2(2), 235-238.

Ravindra Babu, V., Shreya, K., Dangi, K.S., Usharani, G., Nagesh, P., 2012. Genetic variability studies for qualitative and quantitative traits in popular rice (Oryza sativa L.) hybrids of India. International Journal of Scientific and Research Publication 2(6), 1-5.

Reuveni, E., 2011. The genetic background effect on domesticated species: a mouse evolutionary perspective. The Scientific World Journal 11, 429-436.

Sahu, H., Amadabade, J., Kumar, P., Sao, A., Patel, R.K., 2014. Assessment of segregating generations for genetic variability and yield regulating traits in mungbean. The Bioscan 9(4), 1701-1706.

Seyoum, M., Sentayehu, A., Kassahum, B., 2012. Genetic variability, heritability, correlation coefficient and path analysis for yield and yield related traits in upland rice. Journal of Plant Sciences 7(1), 13-20.

Singh, S.K., Singh, C.M., Gil, G.M., 2011. Assesment of genetic variability for yield and its component characters in rice. Research in Plant Biology 1(4), 73-76.

Sohrabi, M., Rafii, M.Y., Hanafi, M.M., Akmar, A.S.N., Latif, M.A., 2012.Genetic diversity of upland rice germplasm in Malaysia revealed by quantitative traits. The Scientific World Journal. DOI: 10.1100/2012 /416291.

Uguru, I.M., 2005. Crop Genetics and Breeding (Revised Edition). Ephrata Press, Nsukka, Nigeria, 113.

Yadav, P., Rangare, N.R., Anurag, P.J., Chaurasia, A.K., 2010. Quantitative analysis of rice (Oryza sativa L.) in Allahabad agro climatic zone. Journal of Rice Research 3(1), 16-18. 